\title{
KARAKTERISASI SIDIK JARI DNA ISOLAT Corynespora cassiicola YANG BERASAL DARI BERBAGAI SENTRA PERKEBUNAN KARET INDONESIA
}

\author{
Characterization of DNA Finger Printing of Corynespora cassiicola \\ Isolates from Different Regions of Rubber Plantation
Fetrina OKTAVIA, M. MUNIR, H. SURYANINGTYAS, dan KUSWANHADI
Balai Penelitian Sembawa, Pusat Penelitian Karet \\ Jalan Raya Palembang - P. Balai KM 29, PO BOX 1127 Palembang 30001
}

Diterima tgl. 19 September 2011/Disetujui 15 Oktober 2011

\begin{abstract}
One of the important steps to obtain a superior clone resistant to Corynespora Leaf Fall Desease (PGDC) is a selection test of resistance of rubber clones to Corynespora cassiicola fungi. To obtain a good result, genetic information of $\mathrm{C}$. Cassiicola isolates used is needed. DNA finger printing of seven C. cassiicola isolates have been done by using $R A P D$ technique. C. cassiicola isolates were isolated from rubber clone of GT 1 derived from seven regions of rubber plantation in Indonesia i.e Bengkulu (CBK), Lampung (CLP), West Kalimantan (CKB), Central Java (CJT), South Sumatra (CSS), Jambi (CJB) and North Sumatra (CSU). The result of RAPD analysis by using 15 primers showed that the genetic diversity of seven C. cassiicola isolates was high (89.3\%). The genetic similarity value amongs the isolates had a variation, of which the highest genetic similarity was found between South Sumatra and Jambi isolates (68.49\%), and the lowest was between Lampung and South Sumatra (51.09\%). The UPGMA analysis showed that the isolates were separated into four groups. It was concluded that 10 of 15 primers used i.e OPN04, OPN-05, OPN-11, OPN-12, OPN-19, OPN20, OPH-04, OPH-09. OPH-12 and OPH-16 could produce a different specific pattern in each of seven isolates. Therefore this technique could be used as an alternative method for the identification of $\mathrm{C}$. cassiicola isolates.
\end{abstract}

Keywords: Hevea brasiliensis, Corynespora cassiicola, genetic analysis, RAPD, primer, UPGMA, leaf fall disease

\section{Abstrak}

Salah satu tahapan penting untuk mendapatkan klon unggul yang tahan terhadap Penyakit Gugur Daun Corynespora (PGDC) adalah uji ketahanan klon-klon karet terhadap serangan jamur Corynespora cassiicola. Untuk mendapatkan hasil yang tepat, diperlukan informasi genetik dari isolat C. cassiicola yang digunakan. Analisis sidik jari DNA dari tujuh isolat C. cassiicola sudah dilakukan dengan menggunakan teknik RAPD. Isolat $C$. cassiicola diisolasi dari klon karet GT 1 di tujuh sentra perkebunan karet di Indonesia yaitu Bengkulu (CBK), Lampung (CLP), Kalimantan Barat (CKB), Jawa Tengah (CJT), Sumatera Selatan (CSS), Jambi (CJB) dan Sumatera Utara (CSU). Hasil analisis RAPD menggunakan 15 primer menunjukkan bahwa keragaman genetik tujuh isolat $C$. cassiicola cukup tinggi (89,3\%). Nilai kesamaan genetik antara isolat bervariasi, dimana kesamaan genetik tertinggi ditemukan antar isolat Sumatera Selatan dengan Jambi yaitu $(68,49 \%)$ dan kesamaan terendah antara isolat Lampung dengan Sumatera Selatan (51,09\%). Analisis UPGMA menunjukkan isolat terbagi ke dalam empat kelompok. Dari 15 primer yang digunakan, 10 primer yaitu OPN-04, OPN-05, OPN-11, OPN-12, OPN-19, OPN-20, OPH-04, OPH-09. OPH-12 dan OPH-16 mampu menghasilkan pola spesifik pada masing-masing isolat, sehingga dapat digunakan sebagai metode identifikasi alternatif.

Kata kunci : Hevea brasiliensis, Corynespora cassiicola, analisis genetik, seleksi klon, RAPD, primer, isolat, UPGMA, penyakit gugur daun 


\section{PENDAHULUAN}

Salah satu tujuan program pemuliaan tanaman karet adalah menghasilkan klonklon unggul yang memiliki produksi tinggi dan tahan terhadap penyakit, antara lain terhadap Penyakit Gugur Daun Corynespora (PGDC) yang disebabkan oleh jamur Corynespora cassiicola. PGDC menyerang tanaman karet pada semua tingkatan umur, baik pada tanaman di pembibitan maupun tanaman menghasilkan. Serangan PGDC mengakibatkan terhambatnya pertumbuhan dan terjadinya penurunan produksi yang cukup signifikan sehingga secara ekonomi sangat merugikan.

Pengendalian PGDC secara kimiawi dirasakan kurang efektif, karena selain berdampak negatif terhadap lingkungan juga memerlukan biaya yang cukup mahal. Salah satu alternatif yang dapat dilakukan untuk mengatasi hal tersebut adalah dengan cara penanaman klon-klon yang tahan terhadap penyakit tersebut, sehingga seleksi klon-klon karet yang tahan perlu dilakukan.

Proses seleksi resistensi klon terhadap PGDC sudah dimulai sejak tahap awal persilangan, yaitu dengan memilih tetua yang memiliki resistensi tinggi. Seleksi lanjutan dilakukan terhadap genotipegenotipe baru hasil persilangan dengan cara pengujian di tingkat laboratorium, kebun kayu okulasi/entres sampai tanaman menghasilkan. Dari pengujian ini ditemukan genotipe-genotipe baru yang memiliki produksi tinggi dan tahan terhadap PGDC. Ada kalanya dari pengujian ditemukan suatu genotipe baru tahan terhadap serangan PGDC pada suatu lokasi, namun tidak tahan bila diuji di lokasi yang berbeda. Selain itu tingkat ketahanan suatu klon terhadap serangan PGDC juga berbeda antar daerah. Hal ini diduga terjadi karena adanya perbedaan ras dari isolat $C$. cassiicola yang menyerang.

C. cassiicola memiliki miselium berwarna coklat kegelapan dan merupakan jamur patogen yang termasuk dalam famili Dentiacea dan genus Corynespora. Jamur ini sudah tersebar di lebih dari 70 negara. Jamur ini tidak hanya menyerang tanaman karet, tapi juga tanaman lainnya dimana sudah tercatat lebih dari 280 spesies tanaman yang meliputi buah-buahan, sayur-sayuran, dan tanaman kehutanan yang terinfeksi jamur tersebut (Farr et al., 2007). Pada tanaman karet, serangan $C$. cassiicola diketahui pertama kali pada tahun 1936 di Sierra Leone, Afrika Barat, dan menyerang perkebunan karet di Indonesia pada tahun 1980. Daerah yang pernah mengalami serangan berat $C$. cassiicola yaitu Sumatera Utara, Sumatera Selatan, Jawa Barat, dan Jawa Tengah (Situmorang et al., 1996).

Salah satu faktor yang mempengaruhi cepatnya penyebaran jamur C. cassiicola adalah kemampuan patogen tersebut membentuk ras baru yang lebih virulen (Situmorang et al., 1996). Klon-klon karet akan memberikan reaksi yang berbeda pada masing-masing ras tersebut. Perbedaan ras dari isolat $C$. cassiicola dapat ditentukan dengan melihat perbedaan morfologi koloninya, bentuk dan ukuran konidia, tingkat patogenisitas dan perbedaan genetik (Darmono et al., 1996; Nghia et al., 2008; Shimomoto et al., 2011). Perbedaan secara morfologi memiliki kelemahan, karena adanya faktor pengaruh lingkungan yang dapat menyebabkan perubahan morfologi. Alternatif terbaik adalah dengan melihat perbedaan genetik yang bebas dari pengaruh lingkungan.

Perbedaan genetik antar isolat dapat terjadi karena adanya mutasi, substitusi, insersi, dan delesi pada materi genetik suatu isolat. Analisis perbedaan genetik suatu patogen dapat dilakukan dengan mengamati sidik jari DNA (DNA finger printing) dari masing-masing isolat dengan menggunakan marka molekuler. Prinsip dasar dari sidik jari DNA tersebut adalah perbedaan polapola fragment DNA yang dihasilkan (Weising et al., 2005).

Analisis molekuler terhadap variasi genetik isolat $C$. cassiicola yang diisolasi dari tanaman karet dari berbagai lokasi sudah banyak dilakukan seperti analisis isolat yang diisolasi dari perkebunan karet di Srilanka dan Australia dengan menggunakan teknik rDNA-ITS dan RFLP (Restriction Fragment Length Polymorphism) (Silva et al., 1998), di Malaysia dengan menggunakan teknik RAPD (Random Amplified Polymorphic DNA), rDNA-ITS (Atan dan Hamid, 2003) dan ISSR (Nghia et al., 
2008), di Cina dengan menggunakan teknik rDNA-ITS (rDNA-Internal Transcribed Spacer) dan ISSR (Inter Simple Sequence Repeat) (Qi et al., 2009, 2010) serta di Jepang dengan menggunakan teknik RAPD (Shimomoto et al., 2011). Untuk Indonesia, analisis isolat $C$. cassiicola dari beberapa sentra perkebunan karet sudah pernah dilakukan oleh Darmono et al. (1996) dan Situmorang (2002) dengan menggunakan teknik RAPD, namun belum terlihat perbedaan genetiknya, sehingga belum dapat digunakan untuk karakterisasi masing-masing isolat. Dengan menggunakan primer yang lebih banyak diharapkan perbedaan genetik antar isolat dapat diperoleh, sehingga dapat dijadikan sebagai alat identifikasi strain isolat yang menyerang suatu klon.

Penelitian ini bertujuan untuk melihat sidik jari DNA tujuh isolat $C$. cassiicola asal klon GT 1 dari beberapa sentra perkebunan karet di Indonesia. Sidik jari tersebut dapat digunakan untuk membedakan masingmasing isolat tersebut sehingga seleksi klon unggul tahan terhadap penyakit gugur daun Corynespora dapat dilakukan lebih tepat.

\section{BAHAN DAN METODE}

\section{Persiapan Isolat}

Penelitian dilaksanakan di Laboratorium Fisiologi, Balai Penelitian Sembawa dari bulan Januari - Juni 2011. Penelitian menggunakan tujuh isolat $C$. cassiicola yang diisolasi dari klon karet GT 1 tahun tanam 2000 di beberapa sentra perkebunan di Indonesia (Tabel 1). Isolat ditumbuhkan dalam media PDA (Potato Dextrose Agar) (500 $\mathrm{mL}$ ekstrak kentang, $10 \mathrm{~g}$ dekstrosa, $15 \mathrm{~g}$ agar, $500 \mathrm{ml}$ aquades) selama 10 hari, kemudian diambil 1 potong $(\mathrm{O}, 5 \mathrm{~mm})$ masing-masing biakan dan dimasukkan ke dalam $100 \mathrm{ml}$ media PDA cair $(500 \mathrm{~mL}$ ekstrak kentang, $30 \mathrm{~g}$ sukrosa, $500 \mathrm{ml}$ aquades). Biakan diinkubasi selama 10 hari pada $24^{\circ} \mathrm{C}$ dan dikocok dengan kecepatan $200 \mathrm{rpm}$.

\section{Ekstraksi DNA}

Ekstraksi DNA dilakukan dengan menggunakan metode CTAB yang dimodifikasi oleh Situmorang (2002). Miselia diambil dari isolat dan dicuci dua kali dengan air steril menggunakan penyaring dua lapis kain kasa. Satu gram miselium digerus dengan nitrogen cair. Tepung miselium dimasukkan ke dalam tabung sentrifus berukuran $16 \mathrm{ml}$ yang berisi buffer ekstraksi [12,6 ml NaCl $5 \mathrm{M}, 2 \mathrm{ml}$ EDTA 0,5 M (pH 8), $5 \mathrm{ml}$ Tris $\mathrm{HCl} 1 \mathrm{M}$ (pH 8), $10 \mathrm{ml} \mathrm{CTAB}$ 10\%, 20,4 ml akuabides]. Campuran dikocok dengan vorteks kemudian diinkubasi pada $65^{\circ} \mathrm{C}$ selama 30 menit. Ke dalam campur-an ditambahkan lagi larutan PCI (Phenol : chloroform : isoamil alkohol $=25: 24: 1$ ), divorteks dan disentrifus dengan kecepatan $11000 \mathrm{rpm}$ selama 15 menit. Supernatan diambil dan dimasukkan ke dalam tabung baru, kemudian ditambahkan larutan CI (chloroform : isoamil alkohol $=24: 1$ ) dan disentrifus dengan kecepatan $11000 \mathrm{rpm}$ selama 5 menit. Supernatan diambil dan dimasukkan ke dalam tabung baru kemudian ditambahkan isopropanol dingin, digoyang pelan kemudian dimasukkan ke dalam freezer pada suhu $4^{\circ} \mathrm{C}$ selama 30 menit. Larutan disentrifus dengan kecepatan $11000 \mathrm{rpm}$ selama 15 menit. Pelet yang terbentuk dicuci dengan etanol $70 \%$ dingin dan disentrifus dengan kecepatan $11000 \mathrm{rpm}$ selama 15 menit, kemudian dikeringkan. Pelet DNA yang diperoleh dilarutkan dalam $1 \mathrm{ml}$ buffer TE [Tris $\mathrm{HCl} 10 \mathrm{mM}$ (pH 8.0), EDTA $1 \mathrm{mM}$ ] dan disimpan pada suhu $4^{\circ} \mathrm{C}$.

\section{Amplifikasi PCR}

Amplifikasi PCR dilakukan menurut metode William et al. (1990) dengan menggunakan 15 primer acak (OPN-04, 05, $11,12,14,15,17,18,19,20$, OPH-04, 08, 09, 12, dan 16) yang berasal dari OPERON Technology. PCR dilakukan dalam volume $25 \mathrm{~L}$ yang terdiri atas 2,5 L DNA template 25 $\mathrm{ng} / \mathrm{L}, 2,5 \mathrm{~L}$ buffer $10 \mathrm{X}+\mathrm{MgCl}_{2}, 2,5 \mathrm{~L}$ dNTP 10 $\mathrm{mM}, 0,5 \mathrm{~L}$ taq DNA polymerase $5 \mathrm{U} / \mathrm{L}, 1 \mathrm{~L}$ primer $10 \mathrm{mM}$ dan $18,3 \mathrm{~L}$ dd $_{2} \mathrm{O}$. Reaksi dilakukan dengan menggunakan mesin PCR T-Personal Biometra (Jerman) dengan kondisi program 45 siklus yang terdiri atas denaturasi selama 1 menit pada suhu $95^{\circ} \mathrm{C}$, annealing 1 menit pada suhu $53^{\circ} \mathrm{C}$ dan extension selama 2 menit pada suhu $72^{\circ} \mathrm{C}$. Siklus terakhir diikuti dengan inkubasi selama 4 menit pada suhu $72^{\circ} \mathrm{C}$. 
Tabel 1. Daerah asal dan kode isolat yang dianalisis Table 1. Origin and code of the analyzed isolates

\begin{tabular}{cccc}
\hline No & $\begin{array}{c}\text { Isolat } \\
\text { Isolate }\end{array}$ & $\begin{array}{c}\text { Asal Wilayah } \\
\text { Origin }\end{array}$ & $\begin{array}{c}\text { Kode Isolat } \\
\text { Isolate Code }\end{array}$ \\
\hline 1 & Corynespora casiicola & Bengkulu & CBK \\
2 & Corynespora casiicola & Lampung & CLP \\
3 & Corynespora casiicola & Kalimantan Barat & CKB \\
4 & Corynespora casiicola & Jawa Tengah & CJT \\
5 & Corynespora casiicola & Sumatera Selatan & CSS \\
6 & Corynespora casiicola & Jambi & CJB \\
7 & Corynespora casiicola & Sumatera Utara & CSU \\
\hline
\end{tabular}

Hasil amplifikasi DNA dianalisis dengan menggunakan $1 \%$ gel agarose dalam $1 X$ buffer TAE $(0,04 \mathrm{M}$ Tris-acetic dalam 1 mM EDTA). Gel diwarnai dengan menggunakan ethidium bromide (Sambrook et al., 1989). Selanjutnya gel difoto di bawah UV transiluminator.

\section{Analisis Data RAPD}

Analisis keragaman genetik isolat $C$. cassiicola dilakukan dengan membuat skor terhadap pita-pita DNA yang dihasilkan. Berdasarkan hasil penskoran disusun dendogram dengan menggunakan program Numerical Taxonomy and Multi-variate Analysis System (NTSYS-pc) versi 1.8 (Rohlf, 1993). Koefisien kesamaan genetik dan jarak genetik dianalisis dengan analisis gerombol yang digunakan untuk menentukan matrik jarak genetik berdasarkan metode Unweighed Pair-Group Averages (UPGMA). Karakterisasi genetik isolat C. cassiicola dilakukan secara visual dengan memperhatikan pola pita DNA yang terbentuk.

\section{HASIL DAN PEMBAHASAN}

\section{Identifikasi Morfologi}

Salah satu cara untuk mengidentifikasi isolat C. Cassiicola adalah dengan melihat perbedaan morfologi koloni yang dihasilkan. Dari tujuh isolat yang dianalisis, ditemukan perbedaan pada bentuk, tekstur, dan warna miselium dari masing-masing isolat. Pada isolat CBK dan
CSU, koloni miselium berbentuk bulat dengan pinggiran rata, tekstur miselium seperti kapas (cottony), dan berwarna putih. Meskipun bentuk dan tekstur miselium sama dengan isolat CBK dan CSU, warna isolat CKB, CJB dan CJT berbeda, dimana isolat CKB berwarna putih agak gelap, CJB gelap kehitaman dan CJT awalnya berwarna putih dan menjadi gelap seiring dengan bertambahnya umur kultur. Isolat CSS berbentuk bulat dengan pinggiran rata, tekstur miselium stelate, warna miselium pada awal inokulasi putih dan seiring bertambahnya umur kultur isolat, warna koloni miselium menjadi gelap atau hitam. Berbeda dengan bentuk keenam isolat lainnya, bentuk isolat CLP tidak beraturan, tekstur seperti kapas dan berwarna putih (Gambar 1).

Perbedaan morfologi antar ketujuh isolat yang diamati tidak berhubungan dengan kedekatan asal geografis, seperti isolat CSS dan CJB yang secara geografis cukup dekat, namun memiliki perbedaan pada tekstur miselium atau CKB dan CSU yang secara geografis cukup jauh tetapi memiliki kesamaan pada bentuk, tekstur dan warna miselum. Hal yang sama juga dilaporkan oleh Darmono et. al (1996), dimana perbedaan morfologi isolat $C$. cassiicola tidak berhubung-an dengan asal klon dan geografis.

Salah satu permasalahan yang dihadapi pada identifikasi isolat berdasarkan perbedaan morfologi adalah perubahan warna miselium akibat perubahan waktu kultur. Hal ini merupakan salah satu kelemahan identifikasi 


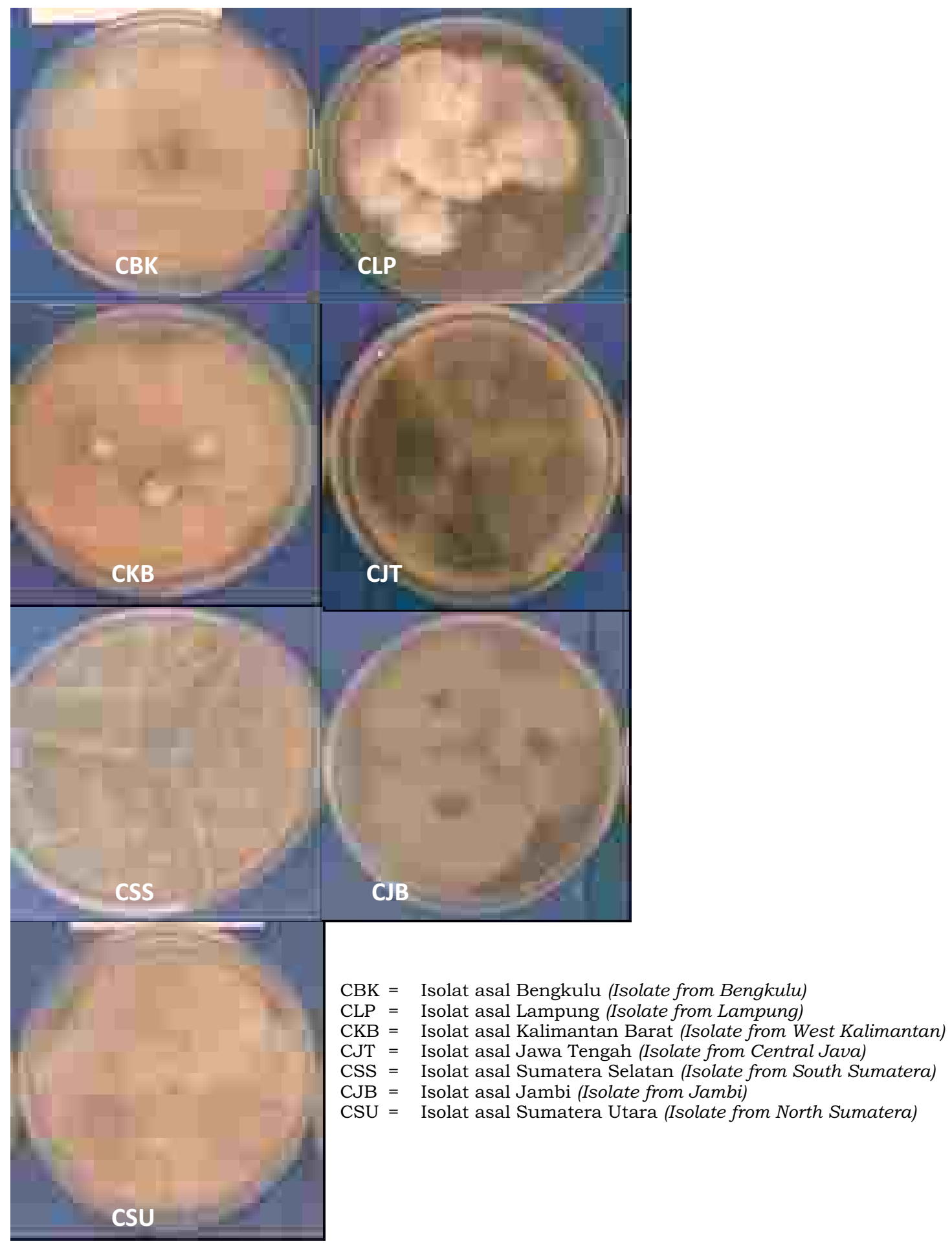

Gambar 1. Morfologi koloni tujuh isolat C. cassiicola

Figure 1. Morphology of colony of seven C. cassiicola isolates 
berdasarkan morfologi karena adanya pengaruh lingkungan yang dapat mengakibatkan perubahan.

\section{Identifikasi Molekuler}

\section{Keragaman genetik isolat C. cassiicola}

Hasil analisis RAPD tujuh isolat $C$. cassiicola yang diisolasi dari klon karet GT 1 dari tujuh sentra perkebunan karet di Indonesia yang diuji dengan 15 primer acak terpilih menunjukkan bahwa polimorfisme DNA ketujuh isolat tersebut cukup tinggi yaitu 89,3\% (Tabel 2). Tingginya polimorfisme DNA yang dihasilkan menunjukkan bahwa keragaman genetik ketujuh isolat tersebut cukup tinggi. Polimorfisme merupakan gambaran amplifikasi yang diperoleh dari perbedaan fragmen DNA yang diamati dan diskor sebagai ada tidaknya perbedaan sekuen, sehingga menunjukkan adanya variasi (Oktavia et al., 2009). Jumlah pita DNA yang dihasilkan oleh masing-masing primer berkisar 5 - 14 pita yang berukuran 150 - 10 $000 \mathrm{bp}$ (Tabel 2). Setiap pita DNA mewakili karakter molekuler yang bersifat spesifik karena merupakan hasil pelipatgandaan satu potongan DNA, namun pita tersebut tidak dapat secara otomatis dianggap berasosiasi dengan sifat tertentu kecuali jika dapat dibuktikan dengan hasil analisis keterpautan (Darmono et al., 1996).

Dari dendogram yang disusun berdasar-kan polimorfisme pita-pita DNA yang dihasilkan terlihat bahwa pada kesamaan genetik $66 \%$ terbentuk 4 kelompok isolat dimana kelompok pertama terdiri dari isolat yang berasal dari Bengkulu (CBK), kelompok kedua terdiri dari isolat Lampung (CLP) dan Sumatera Utara (CSU), kelompok ketiga terdiri dari isolat Kalimantan Barat (CKB), Sumatera Selatan (CSS) dan Jambi (CJB), serta kelompok keempat terdiri dari isolat Jawa Tengah (CJT).

Matrik kesamaan genetik menunjukkan proporsi pita DNA yang sama-sama dimiliki oleh masing-masing isolat. Proporsi kepemilikan pita DNA ini akan menentukan persentase kesamaan genetik antar isolat. Kesamaan genetik tertinggi ditemukan antar isolat Sumatera Selatan dan Jambi yaitu 0,6849 (68,49\%) dan kesamaan terendah antara isolat Lampung dan Sumatera Selatan yaitu 0,5109 (51,09\%) (Tabel 3). Dari hasil analisis tersebut terlihat bahwa tingkat kesamaan genetik masing-masing isolat tidak semuanya tergantung kepada kedekatan lokasi geografis (Gambar 2). Hal yang sama juga ditemukan pada analisis isolat $C$. cassiicola dari sentra perkebunan karet di Malaysia dan Cina.

\section{Sidik Jari DNA Isolat C. cassicola untuk Identifikasi Ras}

Identifikasi isolat C. cassiicola secara molekuler memberikan hasil yang lebih tepat dibandingkan dengan identifikasi secara morfologi, karena identifikasi DNA tidak dilakukan terhadap produk-produk hasil genom dan tidak terpengaruh oleh kondisi lingkungan. Berdasarkan sidik jari DNA yang dihasilkan dari hasil analisis RAPD, maka isolat dapat dibedakan satu sama lain.

Dari 15 primer yang digunakan untuk analisis sidik jari DNA 7 isolat C. cassiicola, 10 primer mampu menghasilkan pola pita DNA yang spesifik pada masing-masing isolat, sementara 5 primer lainnya hanya menghasilkan 2 - 5 pola pita. Primer yang memberikan pola pita spesifik yaitu OPN-04, OPN-05, OPN-11, OPN-12, OPN-19, OPN-20, OPH-04, OPH-09. OPH-12 dan OPH-16. Kesepuluh primer tersebut dapat digunakan untuk membedakan isolat $C$. cassiicola yang berasal dari Bengkulu, Lampung, Kalimantan Barat, Jawa Tengah, Sumatera Selatan, Jambi dan Sumatera Selatan.

Gambar 3 menunjukkan hasil amplifikasi DNA tujuh isolat C. cassiicola yang menghasilkan pola spesifik pada masing-masing isolat dengan menggunakan 10 primer. Jumlah pita DNA yang dihasilkan dari amplifikasi masing-masing primer bervariasi, dimana pada primer OPN-04 berkisar 4 - 8 pita (Gambar 3A), OPN-05 2-6 pita per isolat (Gambar 3B), OPN-11 2-9 pita per isolat (Gambar 3C), OPN-12 2 - 4 pita (Gambar 3D), OPN-19 3 - 7 pita (Gambar 3E), OPN-20 7 - 10 pita (Gambar 3F), OPH-04 4 - 5 pita (Gambar 3G), OPH-09 4 - 9 pita (Gambar $3 \mathrm{H}$ ), OPH-12 2 - 7 pita (Gambar 3I) dan $\mathrm{OPH}-$ 162 - 6 pita (Gambar 3J). 
Tabel 2. Sekuen nukleotida primer RAPD dan jumlah pita DNA yang dihasilkan Table 2. RAPD primer nucleotide sequence and number of DNA fragment produced

\begin{tabular}{|c|c|c|c|c|c|}
\hline \multirow{2}{*}{ No } & \multirow{2}{*}{$\begin{array}{l}\text { Primer } \\
\text { Primer }\end{array}$} & \multirow{2}{*}{$\begin{array}{c}\text { Sekuen primer } \\
5^{\prime} \rightarrow 3^{\prime} \\
\text { Sequence of primer }\end{array}$} & \multicolumn{3}{|c|}{$\begin{array}{l}\text { Jumlah pita DNA } \\
\text { Number of DNA fragments }\end{array}$} \\
\hline & & & Total & $\begin{array}{l}\text { Polimorfik } \\
\text { Polymorphic }\end{array}$ & $\begin{array}{c}\text { Persentase pita polimorfik } \\
\text { Persentage of polymorphic fragment } \\
\text { (\%) }\end{array}$ \\
\hline 1 & OPN-04 & GACCGACCCA & 12 & 11 & 91,7 \\
\hline 2 & OPN-05 & ACTGAACGCC & 8 & 7 & 87,5 \\
\hline 3 & OPN-11 & TCGCCGCAAA & 11 & 11 & 100 \\
\hline 4 & OPN-12 & CACAGACACC & 7 & 6 & 85,7 \\
\hline 5 & OPN-14 & TCGTGCGGGT & 8 & 8 & 100 \\
\hline 6 & OPN-15 & CAGCGACTGT & 7 & 3 & 42,9 \\
\hline 7 & OPN-17 & CATTGGGGAG & 5 & 5 & 100 \\
\hline 8 & OPN-18 & GGTGAGGTCA & 7 & 2 & 28,6 \\
\hline 9 & OPN-19 & GTCCGTACTG & 13 & 13 & 100 \\
\hline 10 & OPN-20 & GGTGCTCCGT & 14 & 14 & 100 \\
\hline 11 & OPH04 & GGAAGTCGCC & 11 & 11 & 100 \\
\hline 12 & OPH08 & GAAACACCCC & 7 & 4 & 57,1 \\
\hline 13 & OPH09 & TGTAGCTGGG & 12 & 12 & 100 \\
\hline 14 & OPH 12 & ACGCGCATGT & 7 & 7 & 100 \\
\hline 15 & OPH 16 & TCTCAGCTGG & 10 & 10 & 100 \\
\hline
\end{tabular}

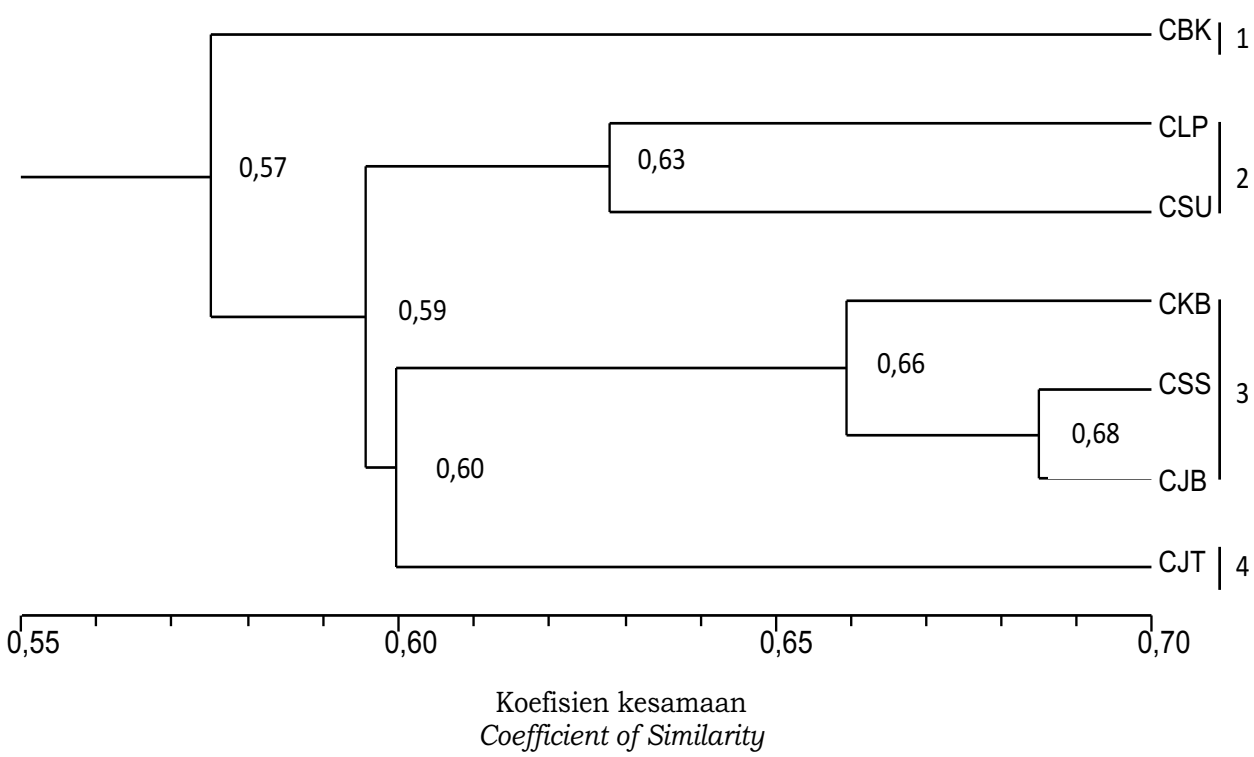

\footnotetext{
$\mathrm{CBK}=$ Isolat asal Bengkulu (Isolate from Bengkulu)

$\mathrm{CLP}=$ Isolat asal Lampung (Isolate from Lampung)

$\mathrm{CKB}=$ Isolat asal Kalimantan Barat (Isolate from West Kalimantan)

$\mathrm{CJT}=$ Isolat asal Jawa Tengah (Isolate from Central Java)

CSS = Isolat asal Sumatera Selatan (Isolate from South Sumatera)

$\mathrm{CJB}=$ Isolat asal Jambi (Isolate from Jambi)

$\mathrm{CSU}=$ Isolat asal Sumatera Utara (Isolate from North Sumatera)
}

Gambar 2. Koefisien kesamaan genetik tujuh isolat C. cassiicola

Figure 2. Coefficient of genetic similarity of seven C. cassiicola isolates 

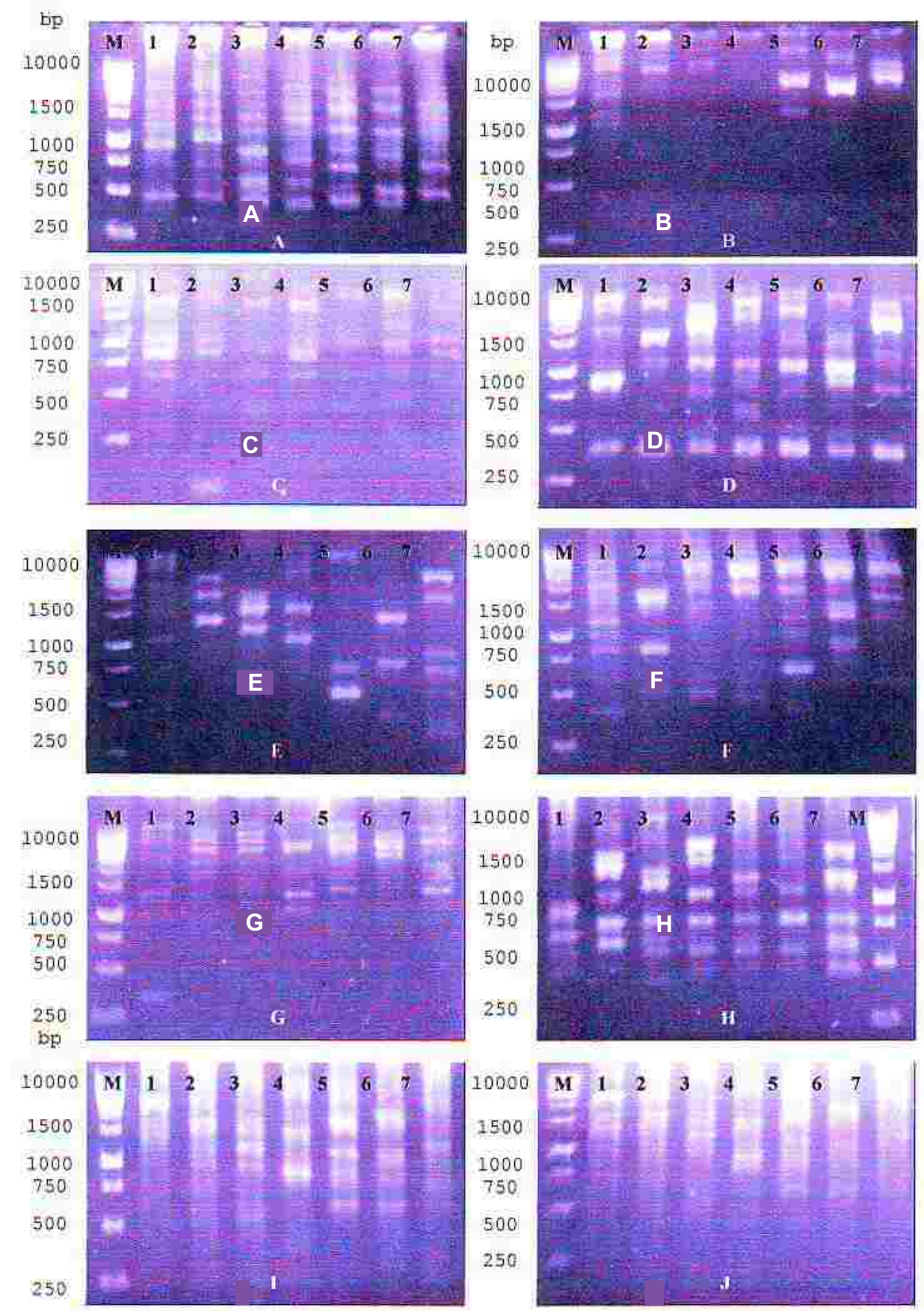

$\mathrm{M}=$ Marker $1 \mathrm{~kb}$ Ladder

1. $\mathrm{CBK}=$ Isolat asal Bengkulu (Isolate from Bengkulu)

2. CLP = Isolat asal Lampung (Isolate from Lampung)

3. $\mathrm{CKB}=$ Isolat asal Kalimantan Barat (Isolate from West Kalimantan)

4. $\mathrm{CJT}=$ Isolat asal Jawa Tengah (Isolate from Central Java)

\begin{abstract}
5. $\mathrm{CSS}=$ Isolat asal Sumatera Selatan (Isolate from South Sumatra)

6. $\mathrm{CJB}=$ Isolat asal Jambi (Isolate from Jambi)

7. CSU = Isolat asal Sumatera Utara (Isolate from North Sumatra)
\end{abstract}

Gambar 3. Amplifikasi PCR yang menghasilkan pola spesifik pada tujuh isolat C. cassiicola dengan menggunakan primer OPN-04 (A), OPN-05 (B), OPN-11 (C), OPN-12 (D), OPN-19(E), OPN-20 (F), OPH-04 (G), OPH-09 (H), OPH-12 (I) dan OPH-16 (J).

Figure 3. PCR amplification yielding specific pattern on seven C. cassiicola isolates by using OPN-O4 (A), OPN-O5 (B), OPN-11 (C), OPN-12 (D), OPN-19(E), OPN-2O (F), OPH-O4 (G), OPH-O9 (H), OPH$12(\mathrm{I})$ and $\mathrm{OPH}-16(\mathrm{~J})$ primers 
Tabel 3. Koefisien kesamaan genetik tujuh isolat C. cassiicola

Table 3. Genetic similarity coefficient among seven C. cassiicola isolates

\begin{tabular}{lccccccc}
\hline $\begin{array}{l}\text { Isolat } \\
\text { Isolate }\end{array}$ & CBK & CLP & CKB & CJT & CSS & CJB & CSU \\
\hline CBK & 1,0000 & & & & & & \\
CLP & 0,5735 & 1,0000 & & & & & \\
CKB & 0,5890 & 0,5455 & 1,0000 & & & & \\
CJT & 0,5793 & 0,6107 & 0,5816 & 1,0000 & & & \\
CSS & 0,5695 & $\mathbf{0 , 5 1 0 9}$ & 0,6667 & 0,5890 & 1,0000 & & \\
CJB & 0,6207 & 0,6565 & 0,6525 & 0,6286 & $\mathbf{0 , 6 8 4 9}$ & 1,0000 & \\
CSU & 0,5185 & 0,6281 & 0,5649 & 0,5846 & 0,6471 & 0,6462 & 1,0000 \\
\hline
\end{tabular}

$\mathrm{CBK}=$ Isolat asal Bengkulu (Isolate from Bengkulu)

CLP = Isolat asal Lampung (Isolate from Lampung)

$\mathrm{CKB}=$ Isolat asal Kalimantan Barat (Isolate from West Kalimantan)

$\mathrm{CJT}$ = Isolat asal Jawa Tengah (Isolate from Central Java)

$\mathrm{CSS}=$ Isolat asal Sumatera Selatan (Isolate from South Sumatera)

$\mathrm{CJB}=$ Isolat asal Jambi (Isolate from Jambi)

$\mathrm{CSU}=$ Isolat asal Sumatera Utara (Isolate from North Sumatera)

Hasil amplifikasi DNA dengan 5 primer yang tidak menghasilkan pola spesifik pada semua isolat dapat dilihat pada Gambar 4. Amplifikasi DNA dengan primer OPN-14 menghasilkan 4 pola berbeda dengan jumlah pita DNA 0 - 7 per isolat. Pola pertama ditemukan pada isolat yang berasal dari Bengkulu, pola kedua pada isolat yang berasal dari Lampung, Jawa Tengah dan Jambi, pola ketiga pada isolat yang berasal dari Kalimantan Barat dan pola ke empat pada isolat yang berasal dari Sumatera Selatan. Sementara itu pada isolat yang berasal dari Sumatera Utara tidak dihasilkan pita DNA (Gambar 4A).

Gambar 4B menunjukkan hasil amplifikasi dengan primer OPN-15 yang menghasilkan 3 pola berbeda. Pola pertama ditemukan pada isolat yang berasal dari Bengkulu dan Jawa Tengah, pola kedua pada isolat yang berasal dari Lampung, Jambi, dan Sumatera Utara, serta pola ketiga pada isolat yang berasal dari Kalimantan Barat dan Sumatera Selatan.

Hasil amplifikasi dengan primer OPN17 menghasilkan 5 pola pita yang berbeda. Pola pertama ditemukan pada isolat yang berasal dari Bengkulu, pola kedua pada isolat yang berasal dari Kalimantan Barat, pola ketiga pada isolat dari Jawa Tengah, pola keempat pada isolat dari Sumatera Selatan dan pola kelima pada isolat dari Jambi dan Sumatera Utara. Jumlah pita DNA yang dihasilkan masing-masing isolat berkisar 0 - 4 pita, dimana isolat dari
Lampung tidak meng-hasilkan pita DNA (Gambar 4C).

Amplifikasi DNA dengan menggunakan primer OPN-18 menghasilkan 2 pola, dimana isolat yang berasal dari Kalimantan Barat memiliki pola yang berbeda dengan keenam isolat lainnya. Perbedaan itu ditentukan oleh satu pita DNA spesifik berukuran 250 bp yang hanya ditemukan pada isolat dari Kalimantan Barat. Jumlah pita DNA yang dihasilkan masing-masing isolat adalah 6 (Gambar 4D).

Gambar 4E menunjukkan hasil amplifikasi dengan primer OPH-08 yang menghasilkan 5 pola berbeda. Pola pertama ditemukan pada isolat yang berasal dari Bengkulu dan Lampung, pola kedua pada isolat dari Kalimantan Barat, pola ketiga pada isolat dari Jawa Tengah, pola keempat pada isolat dari Sumatera Selatan, dan pola kelima pada isolat dari Jambi dan Sumatera Utara. Jumlah pita DNA yang dihasilkan masing-masing isolat berkisar 3 - 5 pita. Amplifikasi dengan primer OPH-08 menghasilkan 2 pita DNA spesifik yang hanya ditemukan pada isolat dari Jawa Tengah.

Dari hasil amplifikasi DNA diatas terlihat bahwa tidak semua primer mampu menghasilkan pola spesifik, meskipun demikian sudah ditemukan 10 primer yang menghasilkan pola berbeda yang dapat digunakan untuk mengidentifikasi masingmasing isolat. Pola spesifik hasil 15 primer 
Tabel 4. Pola spesifik yang dihasilkan oleh 15 primer pada tujuh isolat C. cassiicola Table 4. Specific pattern produced by 15 primers from seven C. cassiicola isolates

\begin{tabular}{lcccccccc}
\hline No & $\begin{array}{r}\text { Isolat/ } \\
\text { Primer }\end{array}$ & CBK & CLP & CKB & CJT & CSS & CJB & CSU \\
\hline 1 & OPN-04 & 1 & 2 & 3 & 4 & 5 & 6 & 7 \\
2 & OPN-05 & 1 & 2 & 3 & 4 & 5 & 6 & 7 \\
3 & OPN-11 & 1 & 2 & 3 & 4 & 5 & 6 & 7 \\
4 & OPN-12 & 1 & 2 & 3 & 4 & 5 & 6 & 7 \\
5 & OPN-19 & 1 & 2 & 3 & 4 & 5 & 6 & 7 \\
6 & OPN-20 & 1 & 2 & 3 & 4 & 5 & 6 & 7 \\
7 & OPH-04 & 1 & 2 & 3 & 4 & 5 & 6 & 7 \\
8 & OPH-09 & 1 & 2 & 3 & 4 & 5 & 6 & 7 \\
9 & OPH-12 & 1 & 2 & 3 & 4 & 5 & 6 & 7 \\
10 & OPH-16 & 1 & 2 & 3 & 4 & 5 & 6 & 7 \\
11 & OPN-14 & 1 & 2 & 3 & 2 & 4 & 2 & 2 \\
12 & OPN-15 & 1 & 2 & 3 & 1 & 3 & 2 & 2 \\
13 & OPN-17 & 1 & 1 & 2 & 3 & 4 & 5 & 5 \\
14 & OPN-18 & 1 & 1 & 2 & 2 & 2 & 2 & 2 \\
15 & OPH-08 & 1 & 1 & 2 & 3 & 4 & 5 & 5 \\
\hline
\end{tabular}

Angka yang sama pada baris yang sama menunjukkan pola yang sama Same figures in the same row show the same pattern

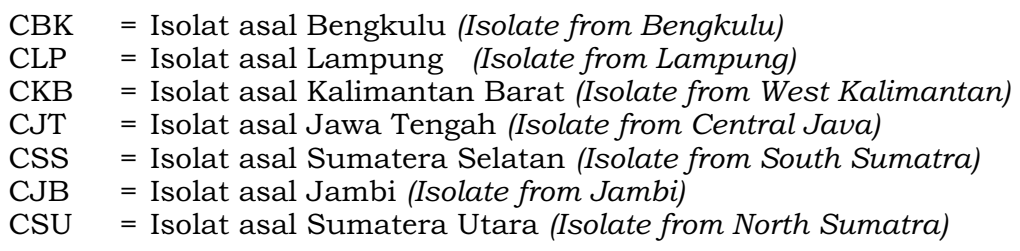

pada 7 isolat $C$. cassiicola disarikan pada Tabel 4.

Dari Tabel 4 diketahui bahwa teknik RAPD dapat digunakan untuk mengidentifikasi isolat $C$. cassiicola, dimana untuk kepentingan identifikasi dibutuhkan minimal dua buah pola spesifik, agar keduanya dapat saling mengkonfirmasi. Dengan menggunakan kombinasi 2 primer dari 10 primer yang menghasilkan pola spesifik maka ketujuh isolat dapat diidentifikasi, sehingga seleksi ketahanan klon terhadap PGDC dapat dilakukan dengan tepat.

\section{Identifikasi Morfologi vs Molekuler}

Secara umum identifikasi spesies jamur dilakukan dengan melihat perbedaan konidia di bawah mikroskop. Namun hal ini susah dilakukan pada spesies yang sama, karena secara umum bentuk konidia suatu spesies adalah sama. Untuk mengatasi hal tersebut biasanya digunakan perbedaan morfologi miselium yang dihasilkan. Dengan memperhatikan ciri-ciri bentuk, tekstur dan warna miselium, tujuh isolat $C$. cassiicola asal klon GT 1 dapat dibedakan. Namun permasalahan yang muncul adalah ciri-ciri tersebut tidak konsisten, dimana seiring perubahan waktu kultur ciri-ciri tersebut juga berubah. Kelemahan identifikasi secara morfologi tersebut dapat dilengkapi dengan identifikasi secara genetik yang tidak dipengaruhi oleh perubahan lingkungan.

\section{KESIMPULAN}

1. Tujuh isolat C. cassiicola dapat diidentifikasi secara morfologi dan genetik dengan menggunakan teknik RAPD. 
2. Dari analisis RAPD menggunakan 15 primer pada 7 isolat C. cassiicola, terbentuk 4 kelompok dengan koefisien kesamaan genetik 66\%, dimana kelompok satu terdiri dari isolat asal Bengkulu, kelompok dua isolat asal Lampung dan Sumatera Utara, kelompok tiga isolat asal Kalimantan Barat, Sumatera Selatan dan Jawa barat dan kelompok empat terdiri dari isolat asal Jawa tengah.

3. Sepuluh dari 15 primer yang diuji mampu menghasilkan pola spesifik pada masing-masing isolat, sehingga kesepuluh primer tersebut dapat digunakan sebagai alat identifikasi isolat C. cassiicola.

4. Pengujian patogenisitas dari masingmasing kelompok ras perlu dilaksanakan sehingga pengendalian yang tepat dapat dilakukan.

\section{DAFTAR PUSTAKA}

Atan, S. and N.H. Hamid. 2003. Differentiating races of Corynespora cassiicola using RAPD and internal transcribed spacer markers. J. Rubb. Res., 6 (1), 58-64.

Anh-Nghia, N., J. Kadir, E. Sunderasan, M.P. Abdullah, A. Malik, and S. Napis. 2008. Morphological and Inter Simple Sequence Repeat (ISSR) markers analyses of Corynespora cassiicola Isolates from rubber plantations in Malaysia. Mycopathologia, 166, 189201.

Darmono, T.W., A. Darussamin, dan S. Pawirosoemardjo. 1996. Keragaman diantara isolat Corynespora cassiicola yang berasosiasi dengan Hevea brasiliensis di Indonesia. Pros. Lok. Penyakit Gugur Daun Corynespora pada Tanaman Karet, 16-17 Desember 1996, Pusat Penelitian Karet, Medan, Indonesia, 79-92.

Farr, D.F., A.Y. Rossman, M.E. Palm, and E.B. McCray. 2007. Fungal Databases. Systematic Botany and Mycology Laboratory, ARS, USDA. http:// nt.arsgrin.gov.
Oktavia, F., M. Lasmingsih dan Kuswanhadi. 2009. Identifikasi klon karet anjuran dengan teknik RAPD. J. Penel. Karet, 27 (1), 21-31.

Qi Y.X., Y.X. Xie, X. Zhang, J. Pu, H.Q. Zhang, S. Huang and H. Zhang. 2009. Molecular and pathogenic variation identified among isolates of Corynespora cassicola. Mol. Biotechnol., 41, 145-151.

Qi, Y.X., X. Zhang, J. Pu, X. Liu, Y. Lu, H. Zhang, H.Q. Zhang, Y.C. Lv, and Y.X. Xie. 2010. Morphological and molecular analysis of genetic variability within isolates of Corynespora cassiicola from different hosts. Eur. $J$. Plant. Pathol., 130 (1), 83-95.

Rohlf, F.J. 1993. NTSYS-PC. Numerical Taxonomy and Multivariate Analisys System. New York, Eeter software.

Sambrook, J.E.F. Fritsch, and Maniatis. 1989. Molecular Cloning : A Laboratory Manual. Cold Spring Harbor Laboratory Press. New York,

Shimomoto, Y., T. Sato, H. Hojo, Y. Morita, S. Takeuchi, H. Mizumoto, A. Kiba and Y. Hikichi. 2011. Pathogenic and genetic variation among isolates of Corynespora cassiicola in Japan. Plant Pathology, 60, 253-260.

Silva, W.P.K., D.S. Multani, B.J. Deverall, and B. Lyon. 1995. RFLP and RAPD analysis in the identification and differentiation of isolates of the leaf spot fungus Corynespora cassiicola. Australian J. Botany, 43, 609-618.

Situmorang, A., A. Budiman, S. Pawiroso em ardjo, d a n M . Lasminingsih. 1996. Epidemi penyakit gugur daun Cory-nespora dan pencegahannya pada tanaman karet. Pros. Lok. Penyakit Gugur Daun Corynespora pada Tanaman Karet, 1617 Desember 1996, Pusat Penelitian Karet, Medan, Indonesia, 111-132. 
Situmorang, A. 2002. Sebaran Penyakit Gugur Daun, Viru-lensi dan Genetika Cory-nespora cassiicola Asal Sentra Perkebunan Karet Indonesia. Disertasi. Institut Pertanian Bogor.

Weising, K., H. Nybom, K. Wolff and G. Kahl. 2005. DNA Finger Printing In Plants, Principles, Methods and Applications. CRC Press, London.
William, J.G.K., A.R. Kubelik, J.A. Livak, K.J. Rafalski, and S.V. Tingey. 1990. DNA poly-morphism amplified by arbitrary primers are useful as genetic markers. Nucleic Acids Res., 18, 6531 6535. 